\title{
OPEN Author Correction: Global airborne microbial communities controlled by surrounding landscapes and wind conditions
}

\section{Romie Tignat-Perrier, Aurélien Dommergue $\mathbb{D}^{\mathrm{D}}$, Alban Thollot, Christoph Keuschnig, Olivier Magand $(\mathbb{D}$, Timothy M. Vogel $[1]$ \& Catherine Larose}

Correction to: Scientific Reports https://doi.org/10.1038/s41598-019-51073-4, published online 08 October 2019

This Article contains errors in Reference 55, which was incorrectly given as:

Pietsch, R. B., David, R. F., Marr, L. C., Vinatzer, B. III. \& D. G. S. Aerosolization of Two Strains (Ice+ and Ice-) of Pseudomonas syringae in a Collison Nebulizer at Different Temperatures. Aerosol Science and Technology 49, 159-166 (2015).

The correct reference is listed below:

Pietsch, R. B., David, R. F., Marr, L. C., Vinatzer, B. \& Schmale, D. G. III. Aerosolization of Two Strains (Ice+ and Ice-) of Pseudomonas syringae in a Collison Nebulizer at Different Temperatures. Aerosol Science and Technology 49, 159-166 (2015).

Furthermore, the Article contains errors in Table 1, where the heading for column 7 should read '16S rRNA gene copies $/ \mathrm{m}^{3}$ ' not ' $16 \mathrm{~S}$ rRNA gene copies $/ \mathrm{m}$ ' and the heading for column 8 should read ' $18 \mathrm{~S} \mathrm{rRNA}$ gene copies $/ \mathrm{m}^{3}$ ' not ' $18 \mathrm{~S}$ rRNA gene copies/m'.

(c) (i) Open Access This article is licensed under a Creative Commons Attribution 4.0 International License, which permits use, sharing, adaptation, distribution and reproduction in any medium or format, as long as you give appropriate credit to the original author(s) and the source, provide a link to the Creative Commons license, and indicate if changes were made. The images or other third party material in this article are included in the article's Creative Commons license, unless indicated otherwise in a credit line to the material. If material is not included in the article's Creative Commons license and your intended use is not permitted by statutory regulation or exceeds the permitted use, you will need to obtain permission directly from the copyright holder. To view a copy of this license, visit http://creativecommons.org/licenses/by/4.0/.

(C) The Author(s) 2020 